\title{
Produtividade e esverdeamento pós-colheita de tubérculos de cultivares de batata produzidos na safra de inverno ${ }^{1}$
}

\author{
Yield and postharvest greening of potato cultivars tubers produced in winter cropping \\ season
}

\author{
Adalton Mazetti Fernandes ${ }^{2}$, Rogério Peres Soratto ${ }^{3 *}$, Regina Marta Evangelista ${ }^{4}$, Beatrice Luciana Silva ${ }^{5}$ e \\ Genivaldo David de Souza-Schlick²
}

\begin{abstract}
Resumo - Cultivares de batata com bom desempenho produtivo e cujos tubérculos sejam resistentes ao esverdeamento, são de grande importância econômica para o setor produtivo. Objetivou-se com esse trabalho avaliar a produtividade, a classificação, o teor de proteína e a resistência ao esverdeamento pós-colheita de tubérculos de cultivares de batata, produzidos na safra de inverno. O experimento foi conduzido durante a safra de inverno de 2008, no município de Itaí, SP. O delineamento experimental utilizado foi o de blocos casualizados, com quatro repetições. Os tratamentos consistiram de cinco cultivares de batata (Ágata, Asterix, Atlantic, Markies e Mondial). Foram avaliados: produtividade, classificação pelo diâmetro transversal, peso médio, teor de proteína e esverdeamento dos tubérculos. As cultivares Mondial, Asterix e Ágata apresentaram maior produtividade total e comercial de tubérculos. A cultivar Mondial apresentou maior produtividade de tubérculos graúdos. A cultivar Atlantic apresentou menor produtividade de tubérculos, porém, com alta porcentagem de tubérculos comercializáveis. As cultivares Markies, Atlantic e Asterix apresentaram maior teor de proteínas nos tubérculos. A cultivar Markies apresentou menor suscetibilidade ao esverdeamento na fase inicial de armazenamento. A cultivar Asterix apresentou maior intensidade de esverdeamento dos tubérculos.
\end{abstract}

Palavras-chave - Solanum tuberosum. Produção de tubérculos. Distúrbio fisiológico. Qualidade pós-colheita.

\begin{abstract}
Potato cultivars with good production performance and with resistance to greening are of great economic importance to the productive sector. This study aimed to evaluate yield, classification, protein content and resistance to postharvest greening of potato tubers of different cultivars. The experiment was carried out during the winter cropping season of 2008 in Itaí, São Paulo State, Brazil. The experimental design was the completely randomized block with four replications. Treatments consisted of five potato cultivars (Ágata, Asterix, Atlantic, Markies and Mondial). Yield, classification by diameter, weight, protein content and greening of tubers were evaluated. Mondial, Asterix and Ágata cultivars showed higher total and commercial tuber yield. Mondial showed higher yield of large tubers. Atlantic showed lower tuber yield, with high percentage of commercial tubers. Markies, Atlantic and Asterix cultivars showed higher protein content of tubers. Markies showed lower susceptibility to the greening in the initial stage of storage. Asterix showed higher intensity of greening in the tubers.
\end{abstract}

Key words - Solanum tuberosum. Tubers production. Physiological disturbs. Postharvest quality.

\footnotetext{
*Autor para correspondência

'Recebido para publicação em 25/02/2010; aprovado em 29/03/2011

Parte da Dissertação de Mestrado do primeiro autor desenvolvido com bolsa do CNPq

2Programa de Pós-Graduação em Agronomia Agricultura, Faculdade de Ciências Agronômicas, Universidade Estadual Paulista /UNESP, Botucatu-SP, Brasil, adalton@fca.unesp.br, genivald@fca.unesp.br

${ }^{3}$ Departamento de Produção Vegetal Agricultura, Faculdade de Ciências Agronômicas, Universidade Estadual Paulista/UNESP, Botucatu-SP, Brasil, soratto@fca.unesp.br

${ }^{4}$ Departamento de Gestão e Tecnologia Agroindustrial, Faculdade de Ciências Agronômicas, Universidade Estadual Paulista/UNESP, Botucatu-SP, Brasil, evangelista@fca.unesp.br

${ }^{5}$ Curso de Graduação em Agronomia, Faculdade de Ciências Agronômicas, Universidade Estadual Paulista/UNESP, Botucatu-SP, Brasil, blsilva@fca.unesp.br
} 


\section{Introdução}

Devido a sua versatilidade gastronômica e tecnológica, a batata (Solanum tuberosum L.) é um dos alimentos mais consumidos no mundo (MÜLLER et al., 2009). No Brasil, o crescimento da safra de inverno e a inclusão de novas áreas de plantio têm permitido o uso de tecnologias mais avançadas e obtenção de maiores produtividades(JULIATTI et al., 2001). No entanto, têm-se priorizado cada vez mais produtos de qualidade (visuais e culinárias) e, cultivares mais produtivas, fato que faz com que grande importância seja dada à aparência dos tubérculos produzidos e a capacidade produtiva das cultivares (SILVA et al., 2007).

No mercado, os consumidores selecionam as batatas através de características visuais como forma e cor dos tubérculos (FELTRAN et al., 2004a), sendo que há uma preferência por tubérculos lisos e brilhantes (SILVA et al., 2008). Assim, a aparência visual, que possui interferência significativa da cor e dos defeitos presentes nos tubérculos, é o primeiro atributo que deve ser considerado, pois, influencia na aceitabilidade pelos consumidores (NOURIAN et al., 2003).

A suscetibilidade dos tubérculos ao distúrbio fisiológico denominado esverdeamento compromete a aceitação pelo mercado consumidor e resulta em prejuízos a toda cadeia produtiva da batata (FELTRAN et al., 2004b). No Brasil, o problema é agravado pela prática de comercializar tubérculos lavados, expostos a granel ou em sacos rendilhados (BRUNE; MELO, 2001).

Os tubérculos de batata são caules modificados com folhas e gemas axilares muito reduzidas, internódios curtos e expansão radial, tendo nos grãos de amido seu componente principal, os quais são sintetizados dentro de plastídeos especializados, denominados de amiloplastos (PETERSON et al., 1985). Quando os tubérculos são expostos à luz, passam por um processo de esverdeamento, devido à transformação dos amiloplastos em cloroplastos (ANSTIS; NORTHCOTE, 1973; GRUNENFELDER et al., 2006), fato que reduz a aceitação comercial. A coloração verde resultante do processo de esverdeamento ocorre em função da síntese da clorofila, em conjunção com pigmentos acessórios no córtex e periderme, sendo, portanto, dependente da cultivar (GRIFFITHS et al., 1994; GRUNENFELDER et al., 2006).

Paralelamente ao desenvolvimento da cor verde, na presença de luz, ocorre a síntese e acúmulo de glicoalcalóides, os quais conferem aos tubérculos sabor amargo e picante e, podem causar intoxicação alimentar se ingeridos em grandes quantidades (MAINE et al., 1988). Dessa forma, a identificação de cultivares de batata com tubérculos resistentes ao esverdeamento e altamente produtivas é importante para aumentar a lucratividade de toda cadeia produtiva da batata.
Diante do exposto, objetivou-se com esse trabalho avaliar a produtividade, a classificação, o teor de proteína e a resistência ao esverdeamento pós-colheita de tubérculos de cultivares de batata, produzidos na safra de inverno.

\section{Material e métodos}

O experimento foi conduzido durante a safra de inverno de 2008, em área produtora de batata no município de Itaí, SP $\left(23^{\circ} 28^{\prime} \mathrm{S} ; 49^{\circ} 08^{\prime} \mathrm{W}\right)$. O solo do local é um Latossolo Vermelho, textura argilosa. A amostragem para a caracterização química do solo na área experimental foi realizada na camada de $0-0,20 \mathrm{~m}$, cujos resultados foram: matéria orgânica, $31,8 \mathrm{~g} \mathrm{dm}^{-3} ; \mathrm{pH}\left(0,01 \mathrm{~mol} \mathrm{~L}^{-1} \mathrm{CaCl}_{2}\right)$, 4,4; $\mathrm{P}_{\text {(resina) }}, 71 \mathrm{mg} \mathrm{dm}^{-3} ; \mathrm{K}, \mathrm{Ca}, \mathrm{Mg}, \mathrm{H}+\mathrm{Al}$ e CTC, 5,6, $28,6,6,1,74,7$ e $115,1 \mathrm{mmol}_{\mathrm{c}} \mathrm{dm}^{-3}$, respectivamente, e saturação por bases, $35,1 \%$. O preparo do solo foi realizado de forma convencional com a seguinte seqüência de operações: dessecação, roçagem, duas gradagens pesadas, escarificação, aração e uma terceira gradagem leve às vésperas do plantio. A adubação de plantio constou da aplicação de $2.100 \mathrm{~kg} \mathrm{ha}^{-1}$ do fertilizante formulado 0430-10, no sulco de plantio.

O plantio foi feito manualmente em 08 de junho de 2008, utilizando-se tubérculos-semente certificados, tipo III (diâmetro entre 30-40 mm). Os tratamentos foram constituídos por cinco cultivares de batata (Ágata, Asterix, Atlantic, Markies e Mondial), no delineamento experimental em blocos ao acaso, com quatro repetições. Cada unidade experimental foi constituída por 10 fileiras de $10 \mathrm{~m}$ de comprimento, no espaçamento de $0,80 \mathrm{~m}$ entre fileiras e $0,35 \mathrm{~m}$ entre plantas. Aos 29 dias após o plantio (DAP) fez-se a adubação de cobertura com $227 \mathrm{~kg} \mathrm{ha}^{-1}$ do formulado 20-05-20 e em seguida realizou-se a amontoa.

A irrigação e o manejo fitossanitário da cultura seguiram as recomendações para a cultura e os critérios adotados pelo produtor. A dessecação da parte aérea de todas as cultivares foi aos 97 DAP. Aos 25 dias após a dessecação das plantas, os tubérculos de 20 plantas das fileiras centrais de cada unidade experimental foram colhidos, lavados e classificados pelo diâmetro transversal (graúda: $>45 \mathrm{~mm}$; primeira: 33 a $45 \mathrm{~mm}$; segunda: 23 a $33 \mathrm{~mm}$ e miúda: $<23 \mathrm{~mm}$ ), sendo considerados comercializáveis aqueles com diâmetro acima de $23 \mathrm{~mm}$. Após classificados, os tubérculos foram contados e pesados para a determinação da produtividade total, comercial e por classes.

O teor de proteína nos tubérculos foi determinado na matéria seca através do nitrogênio total, empregando-se a técnica de Kjeldahl, de acordo com o método 920.87 da AOAC (2000) e, utilizando o fator de 6,25 para conversão em proteína bruta. Em seguida, os dados foram convertidos 
para teores de proteína na matéria fresca e calculou-se a produtividade de proteína por hectare.

Cinco tubérculos da classe especial (graúda) de cada unidade experimental foram armazenados por um período de 30 dias, expostos a luz natural. A intensidade de luz durante o experimento foi medida a cada quatro dias com luxímetro em três horários, às $8 ; 13$ e 16h, em quatro pontos sobre a mesa onde foram dispostos os tubérculos. A intensidade de luz no laboratório, durante o período em que o experimento foi conduzido, foi de $480 \pm 30$ Lux e a temperatura média de $25,3 \pm 3{ }^{\circ} \mathrm{C}$.

As avaliações da intensidade de esverdeamento dos tubérculos foram realizadas na data de montagem do experimento e após $4 ; 8 ; 11 ; 16 ; 21 ; 25$ e 30 dias de exposição dos tubérculos à luz. A cor foi medida em cada tubérculo com colorímetro Minolta modelo CR-400 determinando os parâmetros $\mathrm{L}^{*} \mathrm{a} \mathrm{b}^{*}$. Com os valores de $L^{*}, a^{*}$ e $b^{*}$ foram calculadas as diferenças totais de cor dos tubérculos em relação à cor inicial antes do armazenamento, através da fórmula descrita por Konica Minolta Sensing (1998):

$$
\Delta \mathrm{E}=\sqrt{ }\left(\Delta \mathrm{L}^{*}\right)^{2}+\left(\Delta \mathrm{a}^{*}\right)^{2}+\left(\Delta \mathrm{b}^{*}\right)^{2}
$$

Em que: $\Delta \mathrm{E}=$ valor para diferença de cor; $\Delta \mathrm{L}^{*}=$ diferença entre a leitura $L^{*}$ antes do armazenamento e a leitura $\mathrm{L}^{*}$ em cada época de avaliação; $\Delta \mathrm{a}^{*}=$ diferença entre a leitura $\mathrm{a}^{*}$ antes do armazenamento e a leitura $\mathrm{a}^{*}$ em cada época de avaliação; $\Delta \mathrm{b}^{*}=$ diferença entre a leitura $b^{*}$ antes do armazenamento e a leitura $b^{*}$ em cada época de avaliação.

Os valores de diferença de cor foram comparados com a escala de variação da diferença total de cores (TAB. 1).

Os resultados foram submetidos à análise de variância. As médias referentes às cultivares foram comparadas pelo teste de Tukey ao nivel de 5\% de significância. Para a variável esverdeamento, os efeitos dos períodos de armazenamento foram avaliados por meio de

Tabela 1 - Escala de variação na diferença de cor. (Konica Minolta Sensing, 1998)

\begin{tabular}{cl}
\hline$\Delta \mathrm{E}$ & Diferença de cor \\
\hline$<0,2$ & Imperceptível \\
0,2 a 0,5 & Muito pequena \\
0,5 a 1,5 & Pequena \\
1,5 a 3,0 & Distinguível \\
3,0 a 6,0 & Facilmente \\
6,0 a 12,0 & distinguível \\
$>12,0$ & Grande \\
\hline
\end{tabular}

análise de regressão, adotando-se como critério para escolha do modelo, a magnitude dos coeficientes de regressão significativos ao nível de $5 \%$ de significância pelo teste t.

\section{Resultados e discussão}

Houve diferença entre as cultivares estudadas quanto à produtividade de tubérculos, bem como, quanto à distribuição da produtividade por classes (TAB. 2). As maiores produtividades totais de tubérculos foram obtidas para as cultivares Mondial (40.908 $\mathrm{kg} \mathrm{ha}^{-1}$ ) e Asterix (40.002 kg ha $\mathrm{kg}^{-1}$, seguidas da cultivar Ágata (37.268 $\left.\mathrm{kg} \mathrm{ha}^{-1}\right)$. As menores produtividades foram obtidas para as cultivares Markies (28.624 kg ha-1) e Atlantic (22.544 kg ha-1). Feltran e Lemos (2005) na safra das águas em São Manoel-SP, obtiveram produtividades de $50.100 ; 20.600$ e $28.600 \mathrm{~kg} \mathrm{ha}^{-1}$ para as cultivares Mondial, Asterix e Ágata, respectivamente.

Com relação à produtividade de tubérculos comercializáveis, os resultados foram semelhantes aos obtidos para a produtividade total, sendo que todas as cultivares apresentaram mais de 99,4\% dos tubérculos classificados como comercializáveis (TAB. 2), o que pode estar relacionada com a época de cultivo, ou seja, como as condições favoráveis no cultivo de inverno, em que normalmente tem se observado maiores produtividades (JULIATTI et al., 2001). Feltran e Lemos (2005) verificaram, na época das águas, que a produtividade de tubérculos comercializáveis representou em média apenas $69 \%$ da produção total.

Embora as cultivares Mondial, Asterix e Ágata tenham apresentado as maiores produtividades total e comercial, a cultivar Mondial apresentou maior produtividade de tubérculos da classe "graúda", enquanto que a produtividade de tubérculos da classe "primeira" foi maior nas cultivares Asterix e Ágata (TAB. 2).

Com relação à produtividade de tubérculos da classe "segunda", verificou-se que as cultivares Ágata, Asterix e Mondial apresentaram produtividades semelhantes e superiores às apresentadas pelas cultivares Atlantic e Markies.

Dentre as cultivares estudadas, a menor produtividade (total, comercial e por classes) foi obtida com a cultivar Atlantic, porém, essa cultivar apresentou a maior percentagem de produtividade comercial, com os tubérculos concentrandose na classe graúda, ou seja, a maior parte da produtividade total e do número total de tubérculos produzidos apresentouse com tamanho comercializável (maior que $23 \mathrm{~mm}$ ), o que é desejável, pois a maior uniformidade de tamanho de tubérculos é uma característica importante na seleção de genótipos e cultivares (SILVA et al., 2007). 
Tabela 2 - Produtividade total de tubérculos, distribuição percentual da produtividade e do número de tubérculos por classes das cultivares de batata, na safra de inverno

\begin{tabular}{|c|c|c|c|c|c|}
\hline \multirow{2}{*}{ Cultivares } & \multicolumn{5}{|c|}{ Produtividade de tubérculos $\left(\mathrm{kg} \mathrm{ha}^{-1}\right)$} \\
\hline & Total & Comercial $^{(1)}$ & Graúda & Primeira & Segunda \\
\hline Ágata & $37.268 \mathrm{~b}$ & $37.062 \mathrm{~b}$ & $22.933 \mathrm{c}$ & $12.798 \mathrm{a}$ & $1.330 \mathrm{a}$ \\
\hline Asterix & $40.002 \mathrm{ab}$ & $39.818 \mathrm{ab}$ & $25.451 \mathrm{~b}$ & $13.205 \mathrm{a}$ & $1.160 \mathrm{a}$ \\
\hline Atlantic & $22.544 \mathrm{~d}$ & $22.517 \mathrm{~d}$ & $17.712 \mathrm{~d}$ & $4.456 \mathrm{c}$ & $347 \mathrm{c}$ \\
\hline Markies & $28.624 \mathrm{c}$ & $28.529 \mathrm{c}$ & $19.658 \mathrm{~d}$ & $8.129 \mathrm{~b}$ & $740 \mathrm{~b}$ \\
\hline Mondial & $40.908 \mathrm{a}$ & $40.748 \mathrm{a}$ & $32.113 \mathrm{a}$ & $7.424 \mathrm{~b}$ & $1.209 \mathrm{a}$ \\
\hline$\overline{\mathrm{F}_{\text {calculado }}}$ & $131,36^{* *}$ & $129,67 * *$ & $107,22 * *$ & $41,13^{* *}$ & $79,58 * *$ \\
\hline \multirow[t]{3}{*}{ CV $(\%)$} & 4,11 & 4,12 & 4,61 & 12,65 & 9,53 \\
\hline & \multicolumn{5}{|c|}{ Distribuição da produtividade (\%) } \\
\hline & & Comercial $^{(2)}$ & Graúda $^{(3)}$ & Primeira $^{(3)}$ & Segunda $^{(3)}$ \\
\hline Ágata & & $99,4 \mathrm{~d}$ & $61,9 \mathrm{c}$ & $34,5 \mathrm{a}$ & $3,6 \mathrm{a}$ \\
\hline Asterix & & $99,5 \mathrm{~cd}$ & $64 \mathrm{bc}$ & $33,1 \mathrm{ab}$ & $2,9 \mathrm{~b}$ \\
\hline Atlantic & & 99,9 a & $78,7 \mathrm{a}$ & $19,7 \mathrm{c}$ & $1,6 \mathrm{c}$ \\
\hline Markies & & $99,7 \mathrm{~b}$ & $68,9 \mathrm{~b}$ & $28,5 \mathrm{~b}$ & $2,6 \mathrm{~b}$ \\
\hline Mondial & & $99,6 \mathrm{bc}$ & $78,8 \mathrm{a}$ & $18,2 \mathrm{c}$ & $3,0 \mathrm{~b}$ \\
\hline $\mathrm{F}_{\text {calculado }}$ & & $63,29 * *$ & $41,88^{* *}$ & $38,56^{* *}$ & $35,15^{* *}$ \\
\hline \multirow[t]{3}{*}{ CV (\%) } & & 0,04 & 3,50 & 9,04 & 9,27 \\
\hline & \multicolumn{5}{|c|}{ Distribuição do número de tubérculos (\%) } \\
\hline & & Comercial $^{(2)}$ & Graúda $^{(3)}$ & Primeira $^{(3)}$ & Segunda ${ }^{(3)}$ \\
\hline Ágata & & $36,6 \mathrm{~b}$ & $39,2 \mathrm{~b}$ & $46,6 \mathrm{a}$ & $14,2 \mathrm{ab}$ \\
\hline Asterix & & $39,0 \mathrm{~b}$ & $42,0 \mathrm{~b}$ & $45,0 \mathrm{ab}$ & $13,0 \mathrm{ab}$ \\
\hline Atlantic & & $57,8 \mathrm{a}$ & 59,4 a & 33,9 bc & $6,7 \mathrm{~b}$ \\
\hline Markies & & $43,3 \mathrm{~b}$ & $45,9 \mathrm{~b}$ & $41,5 a b c$ & $12,6 \mathrm{ab}$ \\
\hline Mondial & & $47,0 \mathrm{ab}$ & $51,3 \mathrm{ab}$ & $33,5 \mathrm{c}$ & $15,2 \mathrm{a}$ \\
\hline $\mathrm{F}_{\text {calculado }}$ & & $7,78 * *$ & $7,30 * *$ & $5,97 * *$ & $3,78^{*}$ \\
\hline CV (\%) & & 13,34 & 12,47 & 12,49 & 27,61 \\
\hline
\end{tabular}

Médias seguidas de mesma letra nas colunas não diferem entre si pelo teste Tukey ao nível de $5 \%$ de significância. * e **, significativo ao nível de $5 \%$ e $1 \%$ pelo teste $\mathrm{F}$. ${ }^{(1)}$ Classificação segundo o diâmetro transversal dos tubérculos (comercial: $>23 \mathrm{~mm}$; graúda: $>45 \mathrm{~mm}$; primeira: 33 a $45 \mathrm{~mm}$ e segunda: $23 \mathrm{a} 33 \mathrm{~mm}) .{ }^{(2)}$ Porcentagem em relação à produtividade total. ${ }^{(3)}$ Porcentagem em relação à produtividade comercial

Consorte (2001) relata que a cultivar Atlantic possui característica de apresentar uniformidade na produção, ou seja, alta porcentagem de tubérculos graúdos, o que é um dos aspectos que a torna indicada para a produção de "chips".

A classe especial ou graúda compõe-se de tubérculos com diâmetro superior a $45 \mathrm{~mm}$ tendo maior valor comercial. Nessa classe, a maior porcentagem da produtividade comercial e do número de tubérculos comercializáveis foi obtida com as cultivares Atlantic e Mondial, enquanto que na classe primeira essas variáveis foram maiores para as cultivares Ágata e Asterix (TAB. 2). Esses dados indicam que as cultivares Atlantic e Mondial possuem tendência de produzir maior porcentagem de tubérculos graúdos, enquanto que Ágata e Asterix apresentam distribuição percentual mais proporcional entre as classes graúda e primeira.

Apesar da distribuição percentual da produtividade e do número de tubérculos comerciais na classe graúda terem sido semelhantes entre as cultivares Atlantic e Mondial, a cultivar Mondial possui tubérculos mais pesados (TAB. 3), o que justifica a maior produtividade de tubérculos graúdos obtida nessa cultivar (TAB. 2).

A cultivar Atlantic apresentou tubérculos com peso médio menor que as demais cultivares, o que refletiu em menor produtividade de tubérculos graúdos, 
uma vez que a distribuição percentual da produtividade e da quantidade de tubérculos graúdos foi semelhante entre as cultivares Atlantic e Mondial. Foram observadas diferenças estatísticas quanto ao peso médio de tubérculos da classe primeira entre as cultivares Atlantic, Markies e Asterix, enquanto que na classe segunda o peso médio dos tubérculos foi semelhante entre todas as cultivares.

Quanto à produtividade de proteína, verificase que apesar da cultivar Mondial ter apresentado a maior produtividade total de tubérculos (TAB. 3), sua produtividade de proteína foi inferior à da cultivar Asterix, o que é conseqüência do baixo teor de proteína em seus tubérculos (TAB. 3). Lachman et al. (2005) relatam que os teores de proteína nos tubérculos da batateira são afetados por diversos fatores, tais como, cultivares, sistemas de adubação e sistemas de manejo da cultura.

A cultivar Asterix apresentou alta produtividade de tubérculos e de proteína (TAB. 2 e TAB. 3), o que comercialmente é uma característica interessante, pois, embora a batata não seja, geralmente, considerada como uma fonte de proteína, devido ao seu baixo teor (LACHMAN et al., 2005), ela possui proteína de alto valor nutritivo e, portanto, é uma importante fonte de alimento (BÁRTOVÁ; BÁRTA, 2009). Quanto a cultivar Atlantic, observa-se que, a produtividade de proteína foi inferior às demais cultivares (TAB. 2), devido a menor produção de tubérculos, uma vez que, o teor de proteína nos tubérculos dessa cultivar foi semelhante ao das cultivares Ágata, Asterix e Markies (TAB. 3). Belanger et al. (2002) também não observaram diferenças entre cultivares de batata quanto ao teor de proteína nos tubérculos.

$\mathrm{Na}$ avaliação do esverdeamento pós-colheita, constatou-se interação significativa entre cultivares e período de armazenamento (FIG. 1). Com o aumento do tempo de exposição dos tubérculos à luz, ou seja, maior período de armazenamento houve aumento na diferença de cor da película dos tubérculos $(\Delta \mathrm{E})$ em todas as cultivares estudadas. Resultados semelhantes foram obtidos por vários autores (BRUNE; MELO, 2001; NARDIN, 2009). Muraja-Fras et al. (1994) relatam que o esverdeamento dos tubérculos expostos à luz começa, na verdade, no primeiro dia de exposição à luz, quando os amiloplastos presentes na película dos tubérculos iluminados começam a transformar-se em cloroplastos, e as primeiras indicações de atividade fotossintética já podem ser percebidas com aumento dos teores de clorofila e carotenóides nos tubérculos. Entretanto, para que a quantidade de clorofila acumulada seja suficiente para produzir as primeiras alterações visíveis de coloração na película do tubérculo, são necessários alguns dias (BRUNE; MELO, 2001).

Os tubérculos das cultivares Ágata, Markies e Mondial apresentaram aumento linear na diferença de cor da película $(\Delta \mathrm{E})$ até o final do período de armazenamento, provavelmente porque o tempo total de armazenamento não foi suficiente para a determinação de um ponto de máximo esverdeamento nos tubérculos dessas cultivares. Isso, possivelmente se deve ao fato de que a concentração máxima de clorofila não foi atingida (FELTRAN et al. 2004b). Já nas cultivares Asterix e Atlantic, os dados de intensidade de esverdeamento foram ajustados às funções quadráticas (FIG. 1).

$\mathrm{Na}$ cultivar Asterix a intensidade de esverdeamento foi significativamente maior que na cultivar Markies, nos primeiros 8 dias de armazenamento e, à medida que o período de armazenamento avançou, a cultivar Asterix apresentou um esverdeamento progressivo dos tubérculos até próximo aos 25 dias de armazenamento (FIG. 1), com intensidade/grau de esverdeamento maior que nas demais cultivares entre 11 e 21 dias de armazenamento (FIG. 1). Esses resultados demonstram que os tubérculos da cultivar Asterix são mais suscetíveis ao esverdeamento, devendo

Tabela 3 - Peso médio de tubérculos de cada classe, produtividade e teor de proteína nos tubérculos das cultivares de batata, na safra de inverno

\begin{tabular}{lccccc}
\hline \multirow{2}{*}{ Cultivares } & \multicolumn{2}{c}{ Peso médio de tubérculos $(\mathrm{g})$} & \multirow{2}{*}{ Produtividade de proteína $\left(\mathrm{kg} \mathrm{ha}^{-1}\right)$} & Teor de proteína $^{(1)}(\%)$ \\
\cline { 2 - 4 } & Graúda & Primeira & Segunda & $431,9 \mathrm{ab}$ & $1,16 \mathrm{ab}$ \\
\hline Ágata & $120,3 \mathrm{bc}$ & $56,4 \mathrm{ab}$ & $19,9 \mathrm{a}$ & $548,6 \mathrm{a}$ & $1,37 \mathrm{a}$ \\
Asterix & $150,0 \mathrm{ab}$ & $71,9 \mathrm{a}$ & $23,0 \mathrm{a}$ & $299,9 \mathrm{c}$ & $1,32 \mathrm{a}$ \\
Atlantic & $108,9 \mathrm{c}$ & $47,3 \mathrm{~b}$ & $18,6 \mathrm{a}$ & $427,5 \mathrm{ab}$ & $1,50 \mathrm{a}$ \\
Markies & $150,3 \mathrm{ab}$ & $69,2 \mathrm{a}$ & $24,2 \mathrm{a}$ & $378,4 \mathrm{bc}$ & $0,92 \mathrm{~b}$ \\
Mondial & $178,2 \mathrm{a}$ & $62,1 \mathrm{ab}$ & $23,0 \mathrm{a}$ & $10,62^{* *}$ & $8,64^{* *}$ \\
\hline $\mathrm{F}_{\text {calculado }}$ & $16,00^{* *}$ & $4,99^{*}$ & $0,47^{\mathrm{ns}}$ & 13,33 & 12,06 \\
\hline
\end{tabular}

Médias seguidas de mesma letra nas colunas não diferem entre si pelo teste Tukey ao nível de $5 \%$ de significância. ${ }^{\text {ns }}$, ${ }^{*}$ e* , não significativo, significativo ao nível de $5 \%$ e $1 \%$ pelo teste $\mathrm{F}$. ${ }^{(1)}$ Porcentagem da matéria fresca 
não permanecer por longo período de tempo expostos à luz, pois a cor da película do tubérculo é uma característica importante que afeta efetivamente a aceitação do produto in natura, uma vez que os consumidores preferem batatas de tonalidade clara em relação às mais escuras (NOURIAN ET AL., 2003; SILVA et al., 2008). Esses dados também confirmam os relatos de Griffiths et al. (1994) e Grunenfelder et al. (2006) de que a intensidade de esverdeamento dos tubérculos de batata quando expostos à luz possui também um componente genético, que resulta em diferenças nas reações dos genótipos quando expostos às mesmas condições indutoras, ou seja, é dependente da cultivar. Feltran et al. (2004b) avaliando a intensidade de esverdeamento em tubérculos de 18 cultivares de batata com o método da escala visual de notas e o índice SPAD, observaram que a cultivar Asterix foi suscetível ao esverdeamento com ambos os métodos de avaliação, o que está de acordo com os resultados deste trabalho (FIG. 1). No final do período de armazenamento (30 dias), observou-se que a cultivar Ágata foi a que apresentou a menor intensidade de esverdeamento, o que também foi observado por Feltran et al. (2004b).

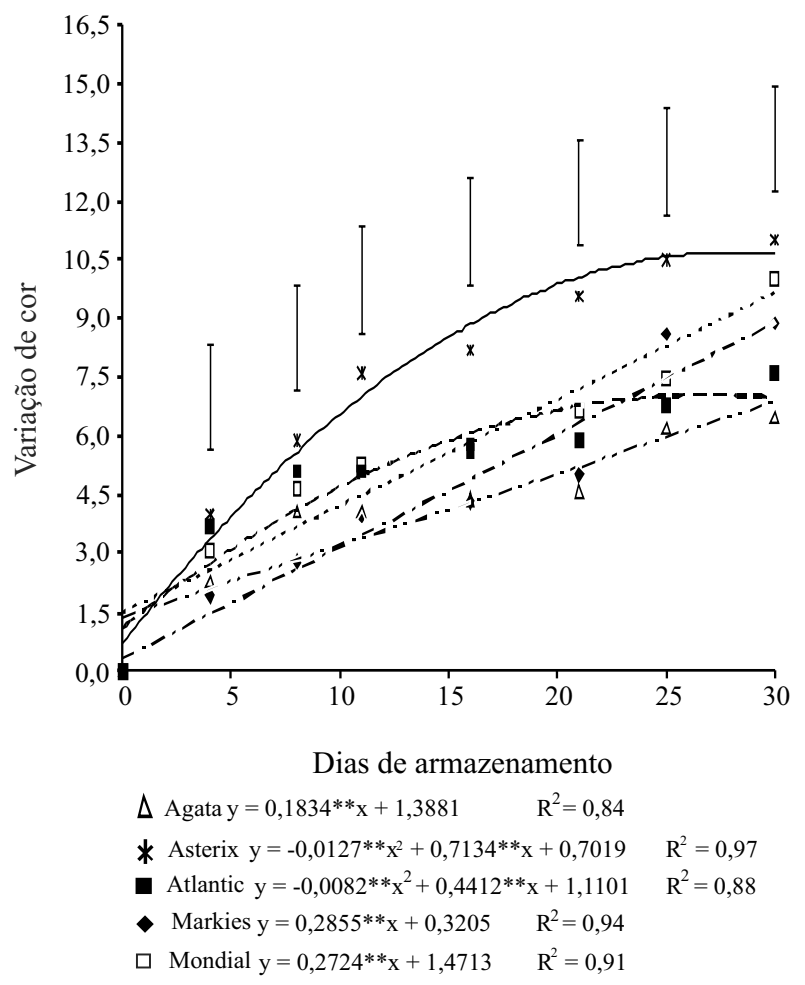

Figura 1 - Diferença de cor $(\Delta \mathrm{E})$ em relação à testemunha, medidos na casca de tubérculos de cultivares de batata, produzidos na safra de inverno, em função do tempo de armazenamento. ${ }^{* *}$ significativo a $1 \%$ pelo teste t. Barras verticais são indicativas do valor de DMS do teste Tukey ao nível de 5\% de significância
Um aspecto importante é que a intensidade de esverdeamento tem maior importância na escolha pelo consumidor do que a velocidade de esverdeamento, já que a partir de quatro dias de exposição à luz notou-se uma diferença de cor média $\left(\Delta \mathrm{E}^{*}\right)$ em relação ao padrão (cor antes do armazenamento), maior que 3,0 para as cultivares Asterix, Atlantic e Mondial (FIG. 1), nos quais a percepção da diferença de cor pode ser feita facilmente de forma visual (TAB. 1) (KONICA MINOLTA SENSING, 1998). Além disso, deve-se considerar também que com o esverdeamento, na presença de luz, ocorrem síntese e acúmulo de glicoalcalóides, que conferem sabor amargo e picante aos tubérculos e, podem causar intoxicação alimentar se ingeridos em grandes quantidades (MAINE et al., 1988).

De maneira geral, o armazenamento teve um efeito típico de induzir o esverdeamento em todas as cultivares estudadas, no entanto, a cultivar Markies apresentou nos primeiros 8 dias de armazenamento uma menor diferença de coloração da epiderme. Já no final do experimento, as maiores variações de cor foram observadas na seguinte ordem: Asterix $>$ Mondial $>$ Markies $>$ Atlantic $>$ Ágata.

\section{Conclusões}

1. As cultivares Mondial, Asterix e Ágata apresentam maior produtividade total e comercial de tubérculos, mas a cultivar Mondial apresenta maior produtividade de tubérculos graúdos;

2. A cultivar Atlantic apresenta menor produtividade de tubérculos, porém, com alta porcentagem de tubérculos comercializáveis;

3. As cultivares Markies, Atlantic e Asterix apresentam maior teor de proteínas nos tubérculos;

4. $\mathrm{Na}$ fase inicial de armazenamento a cultivar Markies apresenta menor suscetibilidade ao esverdeamento e a cultivar Asterix apresenta maior intensidade de esverdeamento dos tubérculos.

\section{Agradecimentos}

Ao Grupo Ioshida pela concessão da área para condução do experimento e à Associação Brasileira da Batata (ABBA) pelo auxílio financeiro. Ao CNPq pela concessão de bolsa de Mestrado ao primeiro autor e de Produtividade em Pesquisa ao segundo autor. À FAPESP pela concessão de bolsa de Iniciação Científica à quarta autora. 


\section{Referências}

ANSTIS, B. J. P.; NORTHCOTE, D. H. Development of chloroplasts from amyloplasts in potato tuber discs. New Phytologist, v. 72, n. 03, p. 449-464, 1973.

ASSOCIATION OF OFFICIAL AGRICULTURAL CHEMISTS. Official methods of analysis of the Association of Analytical Chemists International. 17 ed. Gaithersburg: AOAC, 2000. $1141 \mathrm{p}$.

BÁRTOVÁ, V.; BÁRTA, J. Chemical composition and nutritional value of protein concentrates isolated from potato (Solanum tuberosum L.) fruit juice by precipitation with ethanol or ferric chloride. Journal of Agricultural and Food Chemistry, v. 57, n. 19, p. 9028-9034, 2009.

BELANGER, G. et al. Nitrogen fertilization and irrigation affects tuber characteristics of two potato cultivars. American Journal of Potato Research, v. 79, n. 04, p. 269-279, 2002.

BRUNE, S.; MELO, P. E. Método rápido de avaliação do esverdeamento em tubérculos de batata. Pesquisa Agropecuária Brasileira, v. 36, n. 05, p. 809-814, 2001.

CONSORTE, J. E. fontes e doses de cálcio e nitrogênio na nutrição e produção de batata (solanum tuberosum 1.) para indústria. 2001. 117 f. Tese (Doutorado em Agronomia/ Agricultura) - Universidade Estadual Paulista/Faculdade de Ciências Agronômicas, Botucatu.

FELTRAN, J. C.; LEMOS, L. B. Características agronômicas e distúrbios fisiológicos em cultivares de batata. Científica, v. 33, n. 1, p. 106-113, 2005.

FELTRAN, J. C.; LEMOS, L. B.; VIEITES, R. L. technological quality and utilization of potato tubers. Scientia Agrícola, v. 61, n. 6, p. 598-603, 2004a.

FELTRAN, J.C. et al. Esverdeamento em cultivares de batata avaliado pela escala visual e índice spad. Horticultura Brasileira, v. 22, n. 04, p. 681-685, 2004 b.

GRIFFITHS, D. W.; DALE, M. F. B.; BAIN, H. The effect of cultivar, maturity and storage on photo-induced changes in the total glycoalkaloid and chlorophyll contents of potatoes (Solanum tuberosum L.). Plant Science, v. 98, n. 01, p. 103-109, 1994.

GRUNENFELDER, L.; HILLER, L. K.; Knowles, N. R. Color indices for the assessment of chlorophyll development and greening of fresh market potatoes. Postharvest Biology and Technology, v. 40, n. 01, p. 73-81, 2006.

JULIATTI, F. C.; LUZ, J. M. Q.; BARCELOS, J. E. T. Batata no triângulo mineiro. Batata Show, v. 01, n. 03, p. 28-30, 2001.

KONICA MINOLTA SENSING INC. Comunicação precisa de cor: controle de qualidade da percepção à instrumentação. 53 p. 1998. Disponível em:<www.konicaminolta.com/sensingusa/ support/product_applications $>$. Acesso em: jul. de 2009.

LACHMAN, J.; HAMOUZ, K; DVORÁK, P.; ORSÁK, M. The effect of selected factors on the content of protein and nitrates in potato tubers. Plant Soil Environent. v. 51, n. 10, p. 431-438, 2005.

MAINE, M. J.; BAIN, H.; JOYCE, J. A. L. Changes in the total tuber glycoalkaloid content of potato cultivars when exposed to light. Journal of Agricultural Science, v. 111, n. 01, p. 57-58, 1988.

MULLER, D. R. et al. Expressão dos caracteres e seleção de clones de batata nas condições de cultivo de primavera e outono. Ciência Rural, v. 39, n. 05, p. 1327-1334, 2009.

MURAJA-FRAS, J.; KRSNIK-RASOL, M.; WRISCHER, M. Plastid transformation in greening potato tuber tissue. Journal of Plant Physiology, v. 144, n. 01, p. 58-63, 1994.

NARDIN, I. Qualidade, suscetibilidade ao esverdeamento e aptidão culinária de cultivares de batata (Solanum tuberosum L.). 2009. 96 f. Monografia (Especialização em Ciência e Tecnologia de Alimentos) - Universidade Estadual Paulista/ Faculdade de Ciências Agronômicas, Botucatu.

NOURIAN, F.; RAMASWAMY, H. S.; KUSHALAPPA, A. C. Kinetics of quality change associated with potatoes stored at different temperatures. Lebensmittel-Wissenschaft undTechnologie (Food Science and Technology), v. 36, n. 01, p. 49-65, 2003.

PETERSON, L. R.; BARKER, G. W.; HOWARTH, M. J. Development and structure of tubers. In: LI, P. H. Potato Physiology. Florida: Academic Press, 1985. p.123-152.

SILVA, G. O. et al. Correlações entre caracteres de aparência e rendimento e análise de trilha para aparência de batata. Bragantia, v. 66, n. 03, p. 381-388, 2007.

SILVA, G. O. et al. Qualidade de película de famílias clonais de batata. Bragantia, v. 67, n. 03, p. 633-638, 2008. 